\title{
AIDS mortality trends in Mexico, 1988-1997
}

\author{
Carlos Hernández-Girón, MD, M Sc, ${ }^{(1)}$ Víctor Tovar-Guzmán, MD, MPH , M Sc, ${ }^{(1)}$ \\ Carlos del Río, MD. (2)
}

\section{Hernández-Girón C,Tovar-GuzmánV, Del Río C. Aids mortality trends in Mexico, 1988-1997. Salud Publica Mex 2002;44:207-212. \\ The English version of this paper is available too at: http://www.insp.mx/salud/index.html}

\begin{abstract}
A bstract
Objective.To assess the geographic distribution and trends of AIDS deaths for the 1988-1997 period in Mexico. Material and Methods $C$ rude and adjusted mortality rates were estimated for the 1988-1997 period. A trend test was performed using the simple linear regression method. Standardized mortality ratios (SMR) and years of potential life lost (YPLL) were calculated for each Mexican state. $\mathbf{R e}$ sults. During the study period (1988-1997), there were 26,999 A ID S deaths in Mexico;86.5\% (23,354) of them were among men. The mean age at the time of death was 38.4 years for men and 37.7 years for women ( $p>0.05$ ). The crude AID S mortality rate for the period of study was 3.02 cases (95\% Cl: $2.94,3.06)$ per 100,000 inhabitants. The adjusted rate was 3.13 (95\% Cl: 3.09, 3.17), with 5.22 (95\% $\mathrm{Cl}: 5.16$ - 5.29) for men and 0.82 (95\% Cl: $0.79-0.84)$ for women.The states with the highest SMR were: Baja California (SM R: 248.69; 95\% Cl: 234.02-263.36), Mexico City (SMR: 220.74; 95\% Cl: 215.57-225.91), and Jalisco (SMR: 169.16; 95\% Cl: 162.88-175.44). Similarly, a Potential Lost Life Years Index (PLLYI) analysis by state showed a greater risk of premature AIDS mortality in the same states [Baja California (PLLYI index: 236.33; 95\% Cl: 233.97-238.68), Mexico City (PLLYI: 194.68; 95\% Cl: 193.88 - 195.48), and Jalisco (PLLYI: 170.69; 95\% Cl: 169.60-171.79)]. Conclusions. Mortality trends indicate that AID S mortality in Mexico increased by an annual rate of $23 \%$ between 1988 and 1997.The adjusted AIDS mortality rate increased from 0.75 per 100000 in
\end{abstract}

\author{
Hernández-Girón C,Tovar-Guzmán V, Del Río C. \\ Tendencias de mortalidad por SIDA en México, 1988-1997. \\ Salud Publica Mex 2002;44:207-212. \\ El texto completo en inglés de este artículo también \\ está disponible en: http://www.insp.mx/salud/index.html
}

\section{Resumen}

Objetivo. Determinar la distribución geográfica y la tendencia de mortalidad por SIDA durante el periodo 1988 a 1997, en México. Material y métodos Se estimaron tasas de mortalidad por SIDA, cruda y ajustadas, para el periodo 1988-1997. Se realizó una prueba de tendencia utilizando regresión lineal simple. La razón de mortalidad estandarizada (RME) y los años de vida potencialmente perdidos (AVPP), fueron calculados para cada estado de la República. Resulta dos. Durante el perio do de estudio se reportaron 26999 muertes por SIDA en México, 86.5\% (23 354), fueron hombres. La media de edad al momento de la muerte por esta causa, fue 38.4 años para los hombres y 37.7 años para las mujeres $(p>0.05)$. La tasa cruda de mortalidad por SIDA para el periodo de estudio fue de 3.02 casos (IC 95\% 2.943.06) por 100000 habitantes. La tasa ajustada de mortalidad por SIDA para el periodo de estudio fue de 3.13 casos (IC 95\% 3.09-3.17) por 100000 habitantes. La tasa ajustada de mortalidad para hombres fue de 5.22 casos (IC 95\% 5.16-5.29) por 100000 habitantes; y para mujeres fue de 0.82 casos (IC 95\% 0.79-0.84). Los estados con mayor RME fueron Baja California (RME: 248.69; IC 95\%:234.02-263.36), Distrito Federal (RME: 220.74; IC 95\%: 215.57-225.91), y Jalisco (RME: 169.16; IC 95\%: 162.88-175.44). También se calculó el índice de años de vida potencialmente perdidos (IAVPP), mostrando mayor prematurez en la mortalidad por SIDA, en los mismos estados [Baja California (IAVPP: 236.33; IC 95\%: 233.97-238.68), Distrito Federal (IAVPP:

Presented in part at the "XIII International Conference con AIDS", D urban, South Africa, July 2000. (A bstract \# MoPeD 2498)" "Supported in part by the N IH/A IDS. International Training and Research Program of Emory University Grant \#D 43 TW 01042-0".

(1) Centro de Investigación en Salud Poblacional, Instituto Nacional de Salud Pública, Cuernavaca, Morelos, México.

(2) Emory University School of Medicine. Atlanta, Georgia, United States of A merica. 
1988 , to 4.20 per 100000 in 1997, with the largest burden of mortality in men (male to female ratio of $6: 1$ ). We therefore expect that a decreasing effect on AID S mortality trends will be observed in the next years. The English version of this paper is available too at: http://www.insp.mx/ salud/index.html

Key words:AIDS; mortality trends; Mexico
194.68: IC 95\%: 193.88-195.48), y Jalisco (IAVPP: 170.69; IC 95\%: 169.60-171.79)]. Conclusiones La tendencia de mortalidad por SIDA en México muestra un incremento anual de $23 \%$ entre 1988 y 1997. La tasa ajustada de mortalidad por SIDA se incrementó de 0.75 por 100000 habitantes en 1988 , a 4.20 por 100000 habitantes en 1997. La mayor carga de mortalidad fue en hombres (relación hombre:mujer $6: 1)$. Se espera un efecto decreciente en la mortalidad por esta causa en los siguientes años. El texto completo en inglés de este artículo también está disponible en: http:// www.insp.mx/salud/index.html

Palabras clave: SIDA; tendencia de mortalidad; México
U NAIDS estimates that by the year 2000, thirty-six million people were living with the HIV infection worldwide, most of them in developing countries (70\% corresponding to sub-Saharan Africa). In the Americas, Mexico ranked third place in cumulative AIDS cases reported, following the United States and Brasil. It ranked $15^{\text {th }}$ place, however, according to prevalence rates in adults $(0.29 \%){ }^{1}$

AIDS surveillance in Mexico began in 1986 and, by the end of December 2000, 47617 cases had been reported. However, when underreporting and delays in case notification are considered, the estimated number of AIDS cases could have been as high as 64000 cases. The AIDS epidemic grew exponentially in Mexico between 1987 and 1990, then decreasing in metropolitan areas after 1991; still, the annual incidence rate for the last 3 years was 3.5 cases per 100000 inhabitants..$^{3,4}$

This report provides descriptive epidemiologic data of AIDS mortality trends in Mexico for 1988 to 1997, highlighting the most affected age groups as well as their geographical distribution in the country.

\section{Material and Methods}

Data for this study were obtained from electronic records of AIDS mortality compiled by Instituto Nacional de Estadística, Geografía e Informática (INEGI, the National Statistics, Geography and Informatics Institute). These records include data on age, sex, state of residency, cause of death using the International Classification of Diseases (ICD N²79.5), and year of death. ${ }^{4}$ Mortality Proportional Ratio (MRP) by sex was obtained using the Dever method. Crude mortality rates were obtained using the population projected by the Consejo Nacional de Población (Conapo, National Population Council) as denominator. Adjust- ed mortality rates were obtained by the direct method using the world population structure as the standard population. ${ }^{5}$ Statistical significance of the trend test $(p$ value) was estimated using the simple linear regression method, using the crude and adjusted mortality rates as dependent variables, and the year of death as the independent variable. ${ }^{6}$

The crude AIDS mortality rate trend by 5-year groups was calculated using a simple lineal regression statistical technique; statistical significance of the regression coefficient was assessed with the $p$ value and $95 \%$ confidence intervals $(95 \% \mathrm{CI})$. The working hypothesis tests whether the slope is different from zero (Beta $\neq 0)^{7}$

Standardized Mortality Ratio (SMR) and Potential Lost Life Year Index (PLLYI) with the corresponding 95\% CI were calculated for 1988-1997, by Mexican state. The PLLYI was estimated primarily to evaluate premature mortality from this disease. This indicator is useful in planning health services and establishing priorities in the prevention of premature deaths. ${ }^{5-7}$

\section{Results}

During the ten-year study period (1988-1997), there were 26999 AIDS-related deaths in Mexico, with 86.5\% (23 354) of them among men. The mean age at time of death was 38.4 years for men and 37.7 years for women. The difference in the means was not statistically significant $(p>0.05)$. The group between the ages of 25 to 39 years had a higher relative mortality proportion; it was 59\% for men and 51\% for women. The male to female ratio was 6:1.

The AIDS crude mortality rate for the period of study was 3.02 deaths (95\% CI: 2.94-3.06) per 100000 inhabitants, with 5.22 (95\% CI 5.16-5.29) among men and $0.82(95 \%$ CI $0.79-0.84)$ among women. The 
AIDS adjusted rate was 3.13 deaths (95\% CI: 3.09-3.17) per 100000 inhabitants; for men it was 5.46 (95\% CI 5.39-5.53) and for women, 0.84 (95\% CI 0.82-0.87) (Figure 1).

The percentage of change from the beginning to the end of the $1988-1997$ period was $+545.50 \%$, and the mean annual increase, measured through the geometric mean, was $+23.03 \%$ for the same period. In a comparison by sex, a higher change percentage from 1988 to 1997, and a higher annual increase of mortality rates, were observed in men (Table I).

A trend analysis of crude mortality rates by quinquennial age groups showed the highest rates among the 25-29, 30-34 and 35-39 age groups (Figure 2). The highest slopes corresponded to the 30-34 age group (Beta: $1.0580 ; 95 \%$ CI: $0.8020-1.3143 ; p<0.001$ ) and the 35-39 age group (Beta: 1.0448; 95\% CI: 0.8173-1.2722; $p<0.001$ ). The greatest percentage of change (from 1988 to 1997) was for the 50-54 age group. The mean annual increase was greater for this age group (Table I).

There was a greater proportion of observed deaths than expected, as measured by the SMR in Baja California Norte (SMR: 248.69; 95\% CI: 234.02-263.36), Mexico City (SMR: 220.74; 95\% CI: 214.47-224.91) and Jalisco (SMR:169.16; 95\% CI: 162.88-175.44). The states with the lowest SMR were Zacatecas (SMR: 25.75\%; 95\% CI: 20.68-30.83), Chiapas (SMR: 34.32; 95\% CI: 30.28-38.35), and Durango (SMR 36.54; 95\% CI: 30.8842.21) (Table II).

The total PLLY for this period was 906,050. A PLLYI analysis by state indicated greater and more pre-

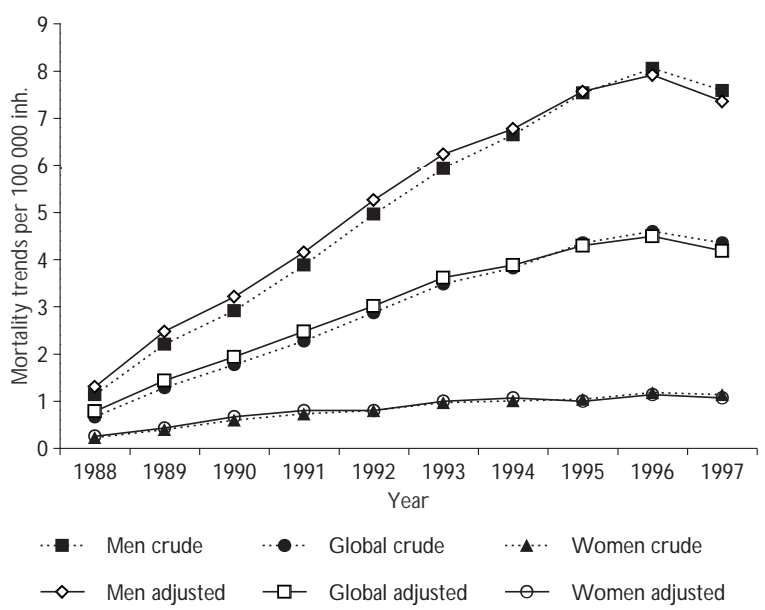

Figure 1. Comparison crude and age-adjusted MORTALITY TRENDS BY SEX FOR AIDS IN MEXICO, 19881997
Table I

\section{Regression sLope, CHANGE PROPORTION AND ANNUAL INCREASE OF CRUDE AIDS MORTALITY RATES, BY AGE GROUPS AND SEX IN MeXICO, 1988-1997}

Age group Beta Coef. $\quad 95 \% \mathrm{Cl} \quad \%$ change 88-97 Annual increase

Total

\begin{tabular}{lllll}
$0-19$ & 0.0193 & $(0.0151-0.0236)$ & +350.00 & +18.19 \\
\hline $20-24$ & 0.2224 & $(0.1746-0.2703)$ & +425.00 & +20.23 \\
\hline $25-29$ & 0.6996 & $(0.5150-0.8842)$ & +536.92 & +22.84 \\
\hline $30-34$ & 1.0580 & $(0.8020-1.3143)$ & +377.59 & +18.97 \\
\hline $35-39$ & 1.0448 & $(0.8173-1.2722)$ & +464.80 & +21.21 \\
\hline $40-44$ & 0.8327 & $(0.6489-1.0164)$ & +391.58 & +19.37 \\
\hline $45-49$ & 0.7002 & $(0.5619-0.8385)$ & +406.67 & +19.76 \\
\hline $50-54$ & 0.5442 & $(0.3943-0.6902)$ & +756.76 & +26.98 \\
\hline $55+$ & 0.3080 & $(0.2405-0.3755)$ & +511.54 & +22.32 \\
\hline Total & 0.4202 & $(0.3325-0.5078)$ & +452.63 & +20.92
\end{tabular}

Male

\begin{tabular}{lllll}
$0-19$ & 0.3921 & $(0.3060-0.4782)$ & +366.67 & +18.67 \\
\hline $20-24$ & 0.4412 & $(0.3463-0.5360)$ & +428.87 & +20.33 \\
\hline $25-29$ & 1.3923 & $(1.0241-1.7605)$ & +520.34 & +20.68 \\
\hline $30-34$ & 2.1154 & $(1.6026-2.6282)$ & +377.48 & +18.98 \\
\hline $35-39$ & 2.0985 & $(1.6416-2.5555)$ & +476.38 & +21.48 \\
\hline $40-44$ & 1.6700 & $(1.3185-2.0215)$ & +395.45 & +19.46 \\
\hline $45-49$ & 1.4082 & $(1.1316-1.6847)$ & +434.90 & +20.47 \\
\hline $50-54$ & 1.0975 & $(0.7970-1.3980)$ & +697.16 & +21.76 \\
\hline $55+$ & 0.6613 & $(0.5165-0.8062)$ & +677.92 & +25.60 \\
\hline Total & 0.8034 & $(0.6738-0.9330)$ & +558.62 & +23.29
\end{tabular}

\begin{tabular}{lllll}
$\begin{array}{c}\text { Female } \\
0-19\end{array}$ & 0.0284 & $(0.0225-0.0342)$ & +400.00 & +19.58 \\
\hline $20-24$ & 0.1050 & $(0.0675-0.1424)$ & +447.62 & +20.80 \\
\hline $25-29$ & 0.1864 & $(0.1110-0.2618)$ & +708.69 & +26.14 \\
\hline $30-34$ & 0.2081 & $(0.1324-0.2840)$ & +384.00 & +19.15 \\
\hline $35-39$ & 0.2415 & $(0.0884-0.3946)$ & +406.25 & +17.59 \\
\hline $40-44$ & 0.1921 & $(0.1137-0.2705)$ & +406.25 & +19.75 \\
\hline $45-49$ & 0.1167 & $(0.0239-0.2573)$ & +256.50 & +15.18 \\
\hline $50-54$ & 0.1138 & $(0.0202-0.2074)$ & +1850.0 & +39.10 \\
\hline $55+$ & 0.0551 & $(0.0330-0.7803)$ & +148.28 & +10.63 \\
\hline Total & 0.1045 & $(0.0806-0.1285)$ & +465.00 & +21.22
\end{tabular}

mature mortality in Baja California (PLLYI: 236.33; 95\% CI: 233.97-238.68), Mexico City (PLLYI: 194.68; 95\% CI: 193.88-195.48), and Jalisco (PLLYI: 170.69; 95\% CI: 169.60-171.79). The states with the lowest PLLYI were Zacatecas (PLLYI: 26.34; 95\% CI: 25.41-27.27), Durango (PLLYI: 39.16; 95\% CI: 38.11-40.22), and Chiapas (PLLYI:39.28; 95\% CI: 38.52-40.03) (Table II). 


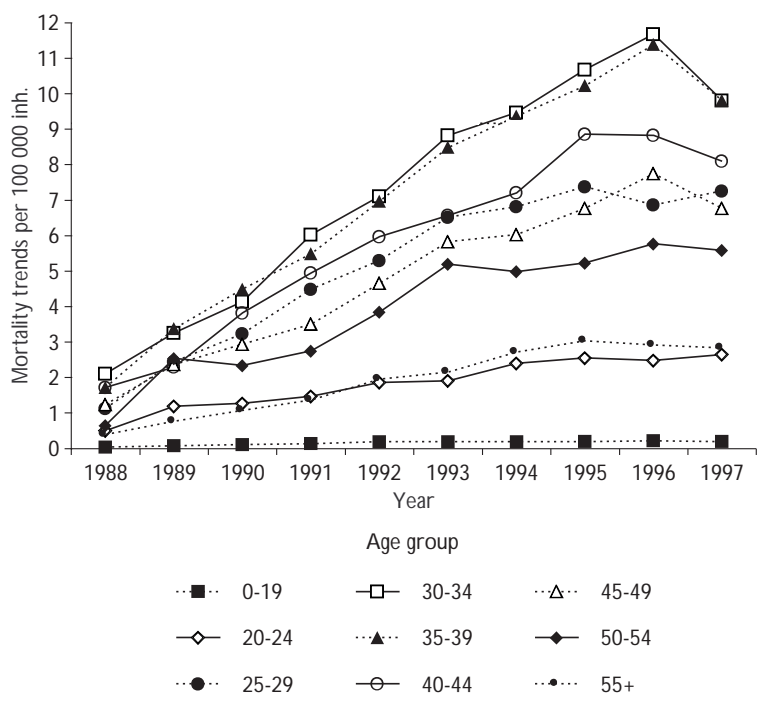

Figure 2. CRUde mortality tRends by AGE GROUP for AIDS IN MEXICO, 1988-1997

\section{Discussion}

WHO estimated that over 21 million people died from AIDS worldwide in 2000 , with $90 \%$ of them in developing countries. These data show that the impact from AIDS, as measured by AIDS-related deaths, is still growing, with an annual increase in the number of both deaths and infections in Latin America. ${ }^{1,8}$

Analysis of AIDS mortality trends in Mexico showed a 22\% increase for the 1989-1997 period. These rates are lower than those for the United States, where the AIDS mortality rate increased by $58 \%$, from 41 per 100000 inhabitants in 1980, to 65 in 1992. ${ }^{9}$ However, there has been a dramatic decrease in AIDS-related deaths in the United States and other developed countries during the past few years, with AIDS deaths declining 42\% between 1996 (36 792 deaths) and 1997 (21 222 deaths), and 20\% between 1997 and 1998 (17 047 deaths).$^{10}$ In Mexico the results show that AIDS mortality patterns increased, globally and by sex, for the 1988-1997 period, however in 1997 they began to stabilize. The real effect of this decline could be observed when the mortality trends analysis included more recent years. ${ }^{11}$

The mean age at death from AIDS for both men and women was 38 years for the 1988-1997 period, with the 25-39 years age groups having the highest relative mortality proportion; this pattern persists. Similar find- ings have been reported in other countries, such as the United States, where the mean age at death from AIDS was 38 years for males and 34 years for females. ${ }^{12}$ In Mexico, the incidence of AIDS-related deaths in 1998 was 4,758 , with $63 \%$ occurring among persons between 20 and 39 years of age. In this age group, AIDS is now the fourth leading cause of death for both sexes.3,13,14

The male to female ratio $(6: 1)$ is similar to that reported for the Andean region of Latin America (6:1), but higher than in the United States, Brasil and Central America (3:1), and the Caribbean (2:1) in 1997. The male to female global ratio has decreased in the United States (from 6:0 in 1991 to 3.0 in 1998), but not in Mexico, where it remained stable during the 1988-1997 period (5.45 in 1991 and 6:1 in 1998). However, we can observe inside the country a range from 3:1 in Puebla, Tlaxcala and Morelos, to 12:1 in Nuevo León. ${ }^{8,15,16}$

AIDS death risks by state showed more observed cases than expected, for both SMR and PLLYI, in Baja California, Mexico City, and Jalisco. In these three states, $43.3 \%$ of cumulative AIDS cases (16 623) reported through January 11999 are concentrated. The major risk factors for HIV infection in these three states wer homosexual and bisexual practices, with 39.8\%, $48.9 \%$, and $37.9 \%$, respectively. Baja California, a state that borders with the United States, has a considerable proportion of cases related to intravenous drug users $(3.5 \%)$, that is greater than the national mean $(0.7 \%){ }^{3}$ If we compare the PLLY for this period (906 050) with that reported by Izazola and collaborators for 1983-1992 (295 749), there is a cumulative increase of $206.37 \% .{ }^{17}$

An important drawback in AIDS data analysis consists of delayed reporting and underreporting of cases, mainly with respect to the basic cause of death, resulting in an underestimation of the results. In Mexico, 47617 AIDS cases were reported through January 1, 2001. Correcting for underdiagnosis and delayed notification (34\%), the actual cumulative number of AIDS cases in Mexico would be closer to a figure of 64000 cases for that year. Similarly, underreporting of AIDS mortality has been estimated to be over 30\%. ${ }^{16,18}$ In Canada and the United States, underreporting of AIDS mortality has been estimated at between 10 and $20 \% .{ }^{10}$ However, our findings are similar to those found elsewhere, regarding the frequency and distribution of AIDS mortality. 3,10,19-21

The fact that antiretroviral treatment is an important marker for the impact of HIV infection should be considered in the development of new strategies for the prevention and control of the AIDS epidemic in Mexico. Contrary to developed countries, we have not observed a decline in AIDS mortality in the study period. In the United States, the use of antiretroviral 
Table II

StANDARDIZED MORTALITY RATIO AND POTENTIAL LOST LIFE YEARS INDEX FOR AIDS MORTALITY IN MEXICO, 1988-1997

\begin{tabular}{|c|c|c|c|c|c|}
\hline State & SMR & $95 \% \mathrm{Cl}$ & YPLL & PLLYI & $95 \% \mathrm{Cl}$ \\
\hline Baja California & 248.69 & $234.02-263.36$ & 38675 & 236.33 & $233.97-238.68$ \\
\hline Ciudad de Mexico & 220.74 & $215.57-225.91$ & 228985 & 194.68 & 193.88-195.48 \\
\hline Jalisco & 169.16 & $162.88-175.44$ & 92667.5 & 170.69 & $169.60-171.79$ \\
\hline Morelos & 144.35 & $132.78-155.2$ & 20292.5 & 143.33 & $141.36-145.30$ \\
\hline Yucatan & 125.04 & $114.40-135.68$ & 18207.5 & 124.35 & $122.55-126.16$ \\
\hline Q uintana Roo & 120.21 & $102.45-137.97$ & 6752.5 & 123.59 & $120.64-126.54$ \\
\hline Puebla & 111.66 & $105.94-117.38$ & 50540 & 123.39 & $122.31-124.46$ \\
\hline $\mathrm{N}$ ayarit & 107.67 & $95.25-120.08$ & 9730 & 111.17 & $108.96-113.38$ \\
\hline Colima & 106.40 & $88.96-123.84$ & 4790 & 102.08 & $99.19-104.97$ \\
\hline Mexico & 99.98 & $96.89-103.07$ & 138357.5 & 90.24 & $89.79-90.72$ \\
\hline Nuevo Leon & 92.14 & $86.20-98.07$ & 31575 & 87.27 & $86.32-88.24$ \\
\hline Guerrero & 82.77 & $76.67-8.88$ & 21142.5 & 83.19 & $82.07-84.31$ \\
\hline Tlaxcala & 74.39 & $62.83-85.95$ & 5802.5 & 85.88 & $83.67-88.09$ \\
\hline Chihuahua & 74.25 & $67.82-80.68$ & 17270 & 70.64 & $69.58-71.69$ \\
\hline Veracruz & 73.51 & $69.92-77.10$ & 57212.5 & 76.28 & $75.66-76.91$ \\
\hline Baja California Sur & 70.71 & $55.11-96.30$ & 2735 & 68.98 & $66.39-71.56$ \\
\hline Tabasco & 61.28 & $53.79-68.77$ & 9667.5 & 70.30 & $68.90-71.70$ \\
\hline Coahuila & 58.86 & $52.77-64.95$ & 11787.5 & 56.85 & $55.82-57.87$ \\
\hline Sinaloa & 58.22 & $52.89-63.55$ & 15555 & 60.39 & $59.44-61.33$ \\
\hline Aguascalientes & 55.65 & $46.01-65.29$ & 4242.5 & 55.39 & $53.72-57.06$ \\
\hline Tamaulipas & 55.46 & $50.00-60.92$ & 13845 & 56.54 & $55.60-57.48$ \\
\hline 0 axaca & 55.43 & $50.32-60.54$ & 16565 & 65.80 & $64.79-66.80$ \\
\hline Michoacan & 50.79 & $46.52-55.07$ & 18200 & 53.03 & $52.26-53.80$ \\
\hline Q ueretaro & 50.36 & $42.56-58.16$ & 5450 & 52.92 & $51.51-54.32$ \\
\hline Campeche & 44.25 & $35.15-53.34$ & 3342.5 & 46.75 & $45.17-48.34$ \\
\hline Guanajuato & 44.25 & $40.37-48.12$ & 17295 & 46.80 & $46.10-47.49$ \\
\hline Sonora & 44.16 & $38.75-49.75$ & 8780 & 42.28 & $41.39-43.60$ \\
\hline San Luis Potosi & 43.02 & $37.98-48.06$ & 9562.5 & 48.14 & $47.17-49.10$ \\
\hline Hidalgo & 40.23 & $36.05-45.41$ & 8370 & 45.88 & $44.90-46.87$ \\
\hline Durango & 36.54 & $30.88-42.21$ & 5292.5 & 39.19 & $38.11-40.22$ \\
\hline Chiapas & 34.32 & $30.28-38.35$ & 10390 & 39.28 & $38.52-40.03$ \\
\hline Zacatecas & 25.75 & $20.68-30.83$ & 3070 & 26.34 & $25.41-27.27$ \\
\hline
\end{tabular}

SMR: Standardized mortality ratio

YPLL:Years of potential lost life

PLLYI: Potential lost life years index

treatment of AIDS patients began in 1994, however in Mexico it was not an important therapeutic option until 1997. Therefore we expect that the effect of decreasing AIDS mortality trends will be observed in the next years.

\section{References}

1. W orld Health O rganization. Annual report on AIDS, Ginebra: W HO, 1997.

2. Consejo N acional de Prevención y Control del SIDA. Boletín Epidemiológico. SIDA/ETS. Revista SIDA/ETS 1997;4(4).
3. Consejo N acional de Prevención y Control del SIDA. Boletín Epidemiológico. SIDA/ETS. Revista SIDA/ETS 1998;4(1-4).

4. O rganización Panamericana de la Salud. Clasificación Internacional de Enfermedades. IX revisión.W ashington, D.C.: O PS, 1978.

5. D ever A . Epidemio logía y administración de servicios de salud.W ashington, D.C.: O PS, 1991.

6. Lilinfield D, Stolley P. Foundations of epidemiology. Third edition. N ueva York: 0 xford University Press, 1994.

7. Hamilton L. Statistics with Stata 3.0, Belmont (CA): Duxbury Press, 1993.

8. 0 rganización Panamericana de la Salud. La epidemia del SIDA: situación en diciembre 1998. W ashington, D.C .: O PS, D ecember 1998.

9. Pinner R, Teustsch S, Simonsen L, Kulg L, G raber J, C larke M et al.Trends in infectious diseases mortality in the United States. JAMA 1996;275(3): 189-193. 
10. Center for D isease Control and Prevention. N ational HIV Prevention Conference. Atlanta (GA): CDC, 1999.

11.Valdespino JL, García ML, D el Río A, Loo-Méndez E, Magis C, Salcedo RA.Epidemiología del SIDA/VIH en México:1983-1995. Salud Publica Mex 1995;37(6):556-571.

12. Heath K, Frank O, Montaner J, $O$ 'Shaughnessy, Schechter M, Hogg R. Human immunodeficiency virus (HIV)/acquired immunodeficiency syndrome (AIDS) mortality in industrialized nations, 1987-1991. Int J Epidemiol 1998;27:685-690.

13. Magis C , D el Río A,Valdespino JL, García ML.C asos de SIDA en el área rural en México. Salud Publica Mex 1995;37(6):615-623.

14. D el Río A, Ligouri A L, Magis C, Valdespino JL, G arcía ML, Sepúlveda J. La epidemia deIVIH/SIDA y la mujer en México. Salud Publica Mex 1995;37(6): 581-591.

15. Sepúlveda J, Del Río A, Valdespino JL, García ML,Velásquez L,Volkow P. La estrategia de prevención de la transmisión del VIH/SIDA a través de la sangre y sus derivados en México. Salud Publica Mex 1995;37(6):624-635.
16. Consejo Nacional de Prevención y Control del SIDA. El SIDA en México en el año 2000. Junio 2001. Reporte preliminar.

17. Izazola JA,Valdez-G arcía MC, Sánchez-Pérez H, D el Río-Chiriboga C. La mortalidad por SIDA en México 1983-1992. Tendencias y años de vida potencialmente perdidos. Salud Publica Mex 1995;37(2):140-148.

18. Anaya-López L. Subestimación de la incidencia de SIDA en México, debida al retraso en la notificación. Revista SIDA/ETS 1997;2(3):35-38.

19. Surasiengsunk $S$, Kiranandana S, W ongboonsin K, Van Griensven G. Demographic impact of the HIV epidemic in Thailand. AIDS 1998;12: 775-784.

20. Laurichesse H, Mortimer J, Evans B, Farrington P. Pre-AIDS mortality in HIV-infected individuals in England, W ales and N othern Ireland, 19821996. AIDS 1998;12:651-658

21. Kristal A.The impact of the AIDS on patterns of premature death in $\mathrm{N}$ ew York C ity. JAMA 1986;255(17):2306-2310. 